\author{
Ljubica Kordić \\ University of Osijek
}

Vesna Cigan

the University College Effectus, College for Finance and Law, Zagreb

\title{
TEACHING AND LEARNING FOREIGN LANGUAGES FOR LEGAL PURPOSES IN CROATIA
}

\begin{abstract}
In accordance with the Bologna Declaration, modern languages and communication skills have a growing importance in all professions. With the prospect of Croatian membership of the EU and taking into consideration the conditions of the growing internationalization of law in general, knowledge of foreign languages represents an indispensable prerequisite for international communication within the legal profession. Thus, teaching foreign languages in the field of law, especially English and German, is necessary not only for the professional education of Croatian law students, but also for their mobility within the network of European universities. This paper presents a case-study of the current situation in teaching Legal English and Legal German in Croatian Law Schools. First, the status of foreign languages for specific purposes (FLSP) in the Higher Education System of the Republic of Croatia in general is analyzed. The main part of the paper is dedicated to teaching Legal English and / or Legal German as compulsory courses within the curricula of Croatian law faculties (status, syllabus design, teaching methods). Then some projects on teaching foreign languages to practicing lawyers will be presented. With the prospect of Croatian membership of the EU, specific education programmes for lawyerlinguists have been introduced by the Law Faculties of Zagreb and Osijek. These programmes, developed within the lifelong education project for lawyers, offer an opportunity for Croatian law students and young lawyers not only to improve their knowledge of Legal English and Legal German, but also to learn other languages of the EU, like French or Italian. These new programmes are the response of Croatian foreign language teachers to the current requirements of the European labour market and the challenges of the internationalization of the modern world.
\end{abstract}

Keywords: Legal English, Legal German, Croatian law faculties, new teaching programmes.

In the Appendix to the Recommendation of the Council of Europe concerning the learning and teaching of modern languages, education institutions are encouraged to ensure resources and provide opportunities for senior secondary students and students of higher and further education to continue learning language appropriate to their programmes of 


\section{Ljubica Kordić and Vesna Cigan}

study and fields of work (Council of Europe, 1982). With the prospect of Croatian membership of the EU and taking into consideration the need to adjust the Croatian law system to that of the European Union, knowledge of foreign languages is an indispensable pre-requisite for the education of Croatian lawyers. The aim of this paper is to inform the wider academic society about the current situation concerning the status of foreign languages for specific purposes (FLSP) in the Higher Education System of the Republic of Croatia in general, with specific reference to teaching Legal English and Legal German in Croatian Law Schools. In the introductory part of this paper the status of FLSP in the Croatian Higher Education System will be presented, while the main part of the discussion will be dedicated to teaching Legal English and Legal German at four Law Faculties in Croatia, with specific reference to the Law Faculty at the University of Osijek. Special attention will be paid to lifelong education programmes introduced by the Law Faculties of Zagreb and Osijek for law students and young lawyers as an answer to the current requirements for Croatian membership of the EU, the European labour market and the challenges of the internationalization of the modern world.

\section{Foreign languages for specific purposes in the Croatian Higher Education System}

According to the Croatian National Education Standard (CNES, 2005), contemporary foreign language teaching is founded on principles of communicative competence in foreign languages, as determined by the Common European Framework of Reference for Languages - CEFR (CEFR, 2005). The National Curriculum Framework (NCF, 2010) contains provisions for foreign language teaching in Croatian secondary schools that are determined in accordance with the CEFR. At the tertiary level of education, the following claim reflects the current situation in Croatia: The higher the education level, the scarcer are the provisions for foreign language teaching (Cigan, 2013). The only legal regulation on higher education, the Scientific Activity and Higher Education Act (Official Gazette No. 123/03, 198/03, 105/04, 174/04, 02/07, 46/07, 45/09, 63/11), barely mentions foreign languages. By granting a high level of autonomy to higher education institutions, it provides for foreign languages only within the framework of individual study programmes and in this respect it points out the importance of harmonization of higher education curricula with the goals and 
achievements of the European tertiary education system. In an attempt to achieve this goal, the Republic of Croatia signed the Bologna Declaration in May 2001. The Bologna process introduced additional requirements in terms of curriculum reform, mobility of students, the teaching and non-teaching staff, and in particular the teaching and learning of foreign languages. It was recognised that the language policies of higher education institutions should include clearly defined activities to promote foreign language learning and the acquisition of linguistic communicative skills as prerequisites for academic mobility within the European Higher Education Area. As determined by the curriculum, students should master a foreign language to such a level, as to be able to read scientific and professional papers in a foreign language, to participate in conferences and use a foreign language in direct communication with native speakers. Due to the autonomy of higher education institutions, these ideas are implemented at Croatian universities in different ways, with different intensity and different approaches to the status and importance of foreign languages. This situation was confirmed by a study on teaching foreign languages at Croatian Universities, which was conducted in 2009 in 143 departments of 5 Croatian Universities (Osijek, Zagreb, Zadar, Rijeka and Split). It showed that $31 \%$ of the departments do not offer LSP to their first year students at all. On the other hand, only $30 \%$ of the departments require FL in the second and third year, whereas only $7 \%$ have an FL course incorporated into their curriculum continuously during 6 semesters (Poljaković \& Martinović, 2009). These data reflect the current situation of FLT in Croatian Higher Schools, indicating that there are a great many discrepancies concerning the status of foreign languages for specific purposes, the intensity of FL courses, as well as the respective ECTS credit allocation and assessment. To illustrate these discrepancies, this paper will present the situation at the Josip Juraj Strossmayer University of Osijek for the academic year 2010/2011. Data are taken from the annual report issued every year by the University - "Sveučilišni godišnjak" (J. J. Strossmayer University, 2011) and refer to BA and MA level studies. It should be stated that students learn mainly English or German. The University encompasses 9 faculties, 1 Academy of Arts and 5 separate departments of: Mathematics, Physics, Biology, Chemistry, and Cultural Studies.

As shown in Table 1, it is difficult to find two faculties within the University in which foreign languages enjoy the same status, are allocated the same number of credits or are allocated the same number of teaching hours per semester. There are many differences between the departments of Physics, Chemistry, Biology and Mathematics. The Department of Chemistry has 
Ljubica Kordić and Vesna Cigan

Table 1

Intensity of FLT indicated by hours and number of ECTS credits at the University of Osijek 2011/12 per semester (sem)

\begin{tabular}{|l|c|c|c|c|c|c|c|c|c|c|c|}
\hline \multicolumn{1}{|c|}{ Faculty } & $\begin{array}{c}1^{\text {st }} \\
\text { sem }\end{array}$ & $\begin{array}{c}2^{\text {nd }} \\
\text { sem }\end{array}$ & $\begin{array}{c}3^{\text {rd }} \\
\text { sem }\end{array}$ & $\begin{array}{c}4^{\text {th }} \\
\text { sem }\end{array}$ & $\begin{array}{c}5^{\text {th }} \\
\text { sem }\end{array}$ & $\begin{array}{c}6^{\text {th }} \\
\text { sem }\end{array}$ & $\begin{array}{c}7^{\text {th }} \\
\text { sem }\end{array}$ & $\begin{array}{c}8^{\text {th }} \\
\text { sem }\end{array}$ & $\begin{array}{c}9^{\text {th }} \\
\text { sem }\end{array}$ & $\begin{array}{c}10^{\text {th }} \\
\text { sem }\end{array}$ & $\begin{array}{c}\text { ECTS } / ~ \\
\text { semester }\end{array}$ \\
\hline Economics & 30 & 30 & 30 & 30 & 30 & 30 & $45 \mathrm{M}$ & $45 \mathrm{M}$ & $45 \mathrm{M}$ & $45 \mathrm{M}$ & $3-5$ \\
Elec. Engineering & $30 \mathrm{el}$ & $30 \mathrm{el}$ & $30 \mathrm{EE}$ & $30 \mathrm{EE}$ & $30 \mathrm{EE}$ & $45 \mathrm{EE}$ & - & - & - & - & $0-3$ \\
Civil Engineering & $30 \mathrm{el}$ & $30 \mathrm{el}$ & - & - & - & - & - & - & - & - & 2 \\
Humanities & 30 & 30 & 30 & 30 & - & - & - & - & - & - & 2 \\
Medicine & 20 & 20 & 20 & 20 & 20 & 20 & 20 & 20 & 20 & 20 & 1 \\
Agriculture & 75 & 75 & - & - & - & - & - & - & $75 \mathrm{el}$ & - & 6 \\
Education & 60 & 60 & $30 \mathrm{El}$ & $30 \mathrm{El}$ & - & - & - & - & - & & 2 \\
Food Technology & 30 & 30 & $30 \mathrm{FT}$ & $30 \mathrm{FT}$ & - & - & - & - & - & - & 2 \\
Academy of Arts & 30 & 30 & 30 & 30 & - & - & - & - & & - & 3 \\
Law & 60 & 60 & 60 & 60 & - & - & - & - & $30 \mathrm{el}$ & - & $3-4,5$ \\
Dept. Maths. & 30 & 30 & 30 & 30 & & & & & & & 3 \\
Dept. Physics & 30 & 30 & 30 & 30 & & & & & & & 2 \\
Dept. Chemistry & 30 & 30 & & & & & & & & & 2 \\
Dept. of Cult. Stud. & 30 & 30 & 30 & 30 & & & & & & & 1 \\
\hline
\end{tabular}

The abbreviations M (Marketing), EE (Electric Engineering) and FT (Food Technology) denote the study groups at specific faculties allocated with more hours of FL than other study groups at those faculties; the abbreviation el stands for "elective course".

LSP only in the first and second semester, and the Departments of Physics and Mathematics, as well as that of Cultural Studies have LSP in the first four semesters. The Department of Biology does not have any foreign languages in its curriculum at all, so this department is not included in the table. On the other hand, the student workload of 30 hours a semester is allocated a different number of credits in different departments: the Department of Mathematics offers 3 ECTS points, the Department of Physics 2 ECTS points, the Department of Chemistry - 2 ECTS points and the Department of Cultural Studies - 1 ECTS point.

With regard to specific faculties, we can see that the data vary from one faculty to another. It should be explained that the data in capital letters attached to some faculties refer to specific study groups being an exception to the rule, in which LSP is taught with more intensity than in other groups of the same faculty. So, $M$ attached to the Faculty of Economics refers to the Study of Marketing, in which students are taught LSP (Business English and 
Business German) throughout all semesters in continuity, whereas in other study groups the teaching period for LSP as a compulsory course takes six semesters (at the BA level). At the BA level the number of credits allocated to the course equals 3 per semester, at the MA level (the Marketing Study group) 5 credits. It should be pointed out that the number of credits for LSP at the MA level of this faculty is the same as that for other courses at that level: 5 ECTS points equally distributed to all the courses. At the faculties of Electrical Engineering and Civil Engineering, LSP is taught only in the first two semesters at the BA level, as elective courses. The number of ECTS points at the faculty of Civil Engineering is 2 per semester, whereas at the Faculty of Electrical Engineering it varies from 0 to 3 credits: for most study groups, LSP has the status of an elective course with no credits allocated, with the exception of the Civil Engineering Study Group, in which only English for Electrical Engineers (German is not offered at all!) is taught as a compulsory course throughout 6 semesters at the BA level with 3 ECTS points allocated in every semester.

As the Faculty of Humanities and Social Sciences includes many study groups, the data presented here refer to two representative study areas: the Study of Psychology and the Study of Croatian Language and Literature (study groups focused on studying foreign languages were not taken into consideration, our topic being languages for specific purposes). In the two respective groups LSP (English or German) is taught as a compulsory course in the first four semesters (BA level) and is allocated 2 ECTS points per semester. A similar situation is present at the Faculty of Education, the only difference being that LSP in the third and the fourth semester is an elective course.

The only faculty in which LSP is taught in continuity from the first to the last semester is the Faculty of Medicine, but only English is taught 20 hours per semester - German is not offered at all. The course is allocated only 1 ECTS point per semester.

At the Faculty of Agriculture, LSP is taught only to first year students $\left(1^{\text {st }}\right.$ and $2^{\text {nd }}$ semester $)$, but more intensely than at other faculties, and the workload of 75 hours of lessons is allocated 6 ECTS points per semester, which is the highest number of credits allocated to LSP within the University of Osijek. In addition, at this faculty, LSP is also offered in the $9^{\text {th }}$ semester as an elective course.

As for the Faculty of Food Technology, LSP as a compulsory course is available only to first year students in all study groups, with the exception of the "main" study programme Food Technology, in which LSP is taught for four semesters at the BA level. The course is allocated 2 credits in every 


\section{Ljubica Kordić and Vesna Cigan}

semester. An interesting example of teaching FLSP is the Academy of Arts, where the choice of the respective FL was made according to the needs of the specific study field: Italian and German are taught within the "Voice" Study Group, while English and German are taught within the "Music" Study Group. In all study groups, foreign languages are taught at the BA level in the first four semesters. In comparison to other faculties at the University of Osijek, the Law Faculty falls within the average range on the ratings of interest: FL for legal purposes is taught in the first four semesters as a compulsory course, but with twice as high intensity as at other faculties. The credits allocated are in mid-range: 3 for compulsory courses and 4.5 for elective courses. The situation at this faculty concerning the status of LSP will be discussed in detail in a comparative study of Croatian law faculties in the main part of the paper.

Consideration of the relevant data concerning LSP in the curricula of the faculties within the University of Osijek demonstrates that the autonomy of the faculties has influenced differences in the status, intensity of teaching, as well as the number of credits allocated to courses. Nevertheless, a slight improvement in the situation can be seen in comparison to the academic year 2005/2006 - the first year of implementation of the Bologna Declaration in Croatian Higher Education - when the number of credits was lower within the University, and at three out of ten faculties (the Departments were established in later years) LSP was an elective course with no credits allocated (Kordić, 2009). In the academic year 2010/11 there were two faculties in which LSP was an elective course, and one of them still had no ECTS credits allocated to the course. This implies that the administrative authorities of higher education institutions have gradually become aware of the importance of FL for their specific fields and have shown an effort to apply the requirements of the Bologna Declaration concerning FLT in a pragmatic approach, attempting to prioritise courses belonging to the area of specific professionalism. Table 2 illustrates these changes.

\section{Foreign Languages at Croatian Law Faculties}

Law Faculties in Croatia are no exception to the general diversity in Croatian universities in their approach to FLSP. Table 3 presents the distribution of foreign language courses (as a rule English or German) at four law faculties in Croatia with reference to their status, intensity of teaching hours per week ( $\mathrm{L}=$ lectures, $\mathrm{E}=$ classes$)$ and the ECTS credits allocated to them. The data refer to integrated BA and MA level courses lasting ten 
Teaching and Learning Foreign Languages for Legal Purposes in Croatia

Table 2

Comparison of ECTS for LSP in 2005/6 and in 2010/11

\begin{tabular}{|l|c|c|}
\hline \multirow{2}{*}{\multicolumn{1}{|c|}{ Faculty }} & \multicolumn{2}{c|}{ Average ECTS per semester } \\
\cline { 2 - 3 } & $2005 / 2006$ & $2010 / 2011$ \\
\hline Faculty of Economics & 3 & $3-5$ \\
Faculty of El. Engineering (elective) & 0 & $0-3$ \\
Faculty of Civil Engineering (elective) & 2 & 2 \\
Law & 3 & $3-4,5$ \\
Humanities & 2 & 2 \\
Education & 2 & 2 \\
Medicine & 1 & 1 \\
Agriculture & 0 & 6 \\
Food Technology & 2 & 2 \\
Academy of Arts & 0 & 3 \\
\hline
\end{tabular}

Table 3

FLT at Croatian law faculties in 2012/13 with number of ECTS credits per semester

\begin{tabular}{|c|c|c|c|c|}
\hline Faculty & Semester & Status & Teaching hours & Credits (ECTS) \\
\hline \multirow{5}{*}{ Law Faculty Osijek } & 1 & Compulsory & $2 \mathrm{~L}+2 \mathrm{E}$ & 3 \\
\hline & 2 & Compulsory & $2 \mathrm{~L}+2 \mathrm{E}$ & 3 \\
\hline & 3 & Compulsory & $2 \mathrm{~L}+2 \mathrm{E}$ & 3 \\
\hline & 4 & Compulsory & $2 \mathrm{~L}+2 \mathrm{E}$ & 3 \\
\hline & 9 & Elective & $2 \mathrm{~L}$ & 4.5 \\
\hline \multirow{5}{*}{ Law Faculty Zagreb } & 1 & Compulsory & $2 \mathrm{E}$ & 2 \\
\hline & 2 & Compulsory & $2 \mathrm{E}$ & 2 \\
\hline & 3 & Compulsory & $2 \mathrm{E}$ & 2 \\
\hline & 4 & Compulsory & $2 \mathrm{E}$ & 2 \\
\hline & 9 & Elective & $2 \mathrm{~L}$ & 4 \\
\hline \multirow{5}{*}{ Law Faculty Rijeka } & 1 & Compulsory & $2 \mathrm{E}$ & 4 \\
\hline & 2 & Compulsory & $2 \mathrm{E}$ & 4 \\
\hline & 3 & Compulsory & $2 \mathrm{E}$ & 4 \\
\hline & 4 & Compulsory & $2 \mathrm{E}$ & 4 \\
\hline & 5 & Elective & $2 \mathrm{~L}$ & 5 \\
\hline \multirow{2}{*}{ Law Faculty Split } & 4 & Compulsory & $2 \mathrm{~L}+1 \mathrm{E}$ & 4 \\
\hline & 5 & Compulsory & $2 \mathrm{~L}+1 \mathrm{E}$ & 4 \\
\hline
\end{tabular}

$(\mathrm{L}=$ lectures $; \mathrm{E}=$ classes $)$ 


\section{Ljubica Kordić and Vesna Cigan}

semesters altogether (at each faculty there is also the study of applied sciences - "Stručni studij" encompassing 6 semesters in which LSP is taught with lower intensity per week and with fewer credits allocated).

Analysis of the data displayed in the Table 3 indicates considerable differences concerning the status, the intensity of FLT per week, as well as the number of credits allocated to LSP. Two out of four law faculties (Zagreb and Osijek) offer LSP as elective courses in the $9^{\text {th }}$ semester ( $5^{\text {th }}$ year). At the Law Faculty in Rijeka FL is offered as an elective course in the $5^{\text {th }}$ semester, whereas FL as an elective course is not included in the curriculum of the Law Faculty in Split. In Zagreb, four elective courses are offered: English in the Field of Law, German in the Field of Law and French in the Field of Law, including the interdisciplinary course Comparative Legal Linguistics. In Osijek, two elective FL courses are offered: Deutsch für Strafrecht and English for EU Law. In Rijeka, the course Terminology of the EU is offered in English and in German. The student workload in LSP as an elective course is granted 5 ECTS points in Rijeka, 4.5 ECTS points in Osijek and 4 ECTS points in Zagreb.

The intensity of teaching LSP as a compulsory course also varies: in Osijek, Zagreb and Rijeka it is taught in 4 semesters and in Split in only two semesters. If we compare the total number of ECTS credits with the number of lectures and classes per week, there are obvious discrepancies between the student workload and the number of credits which vary from one law faculty to another (Tables 4 and 5).

Table 4

Distribution of ECTS credits for LSP at Croatian law faculties

\begin{tabular}{|l|l|c|c|c|c|}
\hline \multicolumn{2}{|c|}{ Law faculty } & Osijek & Zagreb & Rijeka* & Split \\
\hline \multirow{2}{*}{$\begin{array}{l}\text { ECTS Credits } \\
\text { for LSP }\end{array}$} & Compulsory course & 12 & 8 & 16 & 8 \\
\cline { 2 - 6 } & Elective course & 4,5 & 4 & 5 & - \\
\hline
\end{tabular}

Table 5

Intensity of FL as a compulsory course per semester indicated by no. of hours

\begin{tabular}{|l|c|c|c|c|}
\hline \multicolumn{1}{|c|}{ Law faculty } & Osijek & Zagreb & Rijeka & Split \\
\hline Lectures & 30 & 0 & 0 & 30 \\
Exercises & 30 & 30 & 30 & 15 \\
\hline Total No of hours/semester & 60 & 30 & 30 & 45 \\
\hline
\end{tabular}


Even a superficial comparison of the student workload with the number of ECTS credits indicates great differences between Croatian law faculties. Although the number of teaching hours per semester at the Faculty of Law in Osijek is twice as high as that at the other law faculties, the total number of ECTS credits allocated to compulsory courses is relatively low (12 ECTS in Osijek in comparison to 16 in Rijeka). As these data indicate, in spite of the promotion of FL learning by the Council of Europe, the Sorbonne and the Bologna Declaration, its status, intensity of teaching and the recognition of its significance at the state level is diverse and inconsistent not only in higher education in Croatia as a whole, but also within faculties of the same profile. The low number of ECTS credits allocated to foreign language courses in comparison to courses in the field of law, which are allocated a minimum of 5 ECTS points per semester, is perceived by many FL teachers as a form of degradation of foreign languages with respect to the role they are expected to play within the legal profession under circumstances of political and legal integration across the Continent. It seems though, that communicative competence in foreign languages, as promoted by the Bologna Declaration and corresponding international documents, remains appreciated more at the declaratory level, and is still far from having achieved actual implementation at Croatian law faculties. This discouraging situation provided an incentive to conduct a research study into the significance of the knowledge of foreign languages for Croatian lawyers. In two different studies (Kordić, 2009; Poljaković \& Martinović, 2009) it was shown that law students and lawyers consider foreign languages, especially English, important for their profession. Knowledge of German and French is also regarded as being important for the legal profession (Kordić, 2009). Investigation of reference materials used by Croatian lawyers in writing scientific papers indicated that the percentage of those who need or use references in German for their professional work $(22 \%)$ was higher than that of those who learned the language as their first foreign language (16\%). This leads to the conclusion that German should be taught in Croatian law faculties with greater intensity than it actually is. The same might hold for French also, especially in view of the fact that it is not offered in the curricula of Croatian law faculties at all (the only exception is French as an elective course at the Law Faculty in Zagreb), although the language is one of the working languages of the EU (Kordić, 2009). 


\section{Teaching FL at the Law Faculty of Osijek - A Case Study}

As stated in the introduction to this paper, the need to develop foreign language communication skills in the field of law represents a precondition both for law students' professional education and for their mobility within the network of European universities as promoted by the Bologna Declaration. At Croatian law faculties, students are obliged to attend courses in one foreign language - either English or German. The right to choose between English and German represents a problem in many faculties, because, due to the positioning of English as a language of international communication and modern electronic media today, many students choose English rather than German, in spite of the fact that German was their FL 1. For example, in the academic year 2012/2013, in the first year of the Integrated BA and MA studies, there were 175 students learning English and 21 students learning German. It is only as a result of the outstanding efforts on the part of FL teachers, that in last two years the number of students attending German courses has not decreased. Special activities include promotional lectures for future law students on Career Day, organized once a year at the Law Faculties in Zagreb and Osijek; extracurricular activities promoting the learning of German; reports on web-pages of the faculty and in local newspapers on the results of FL international projects and programmes, etc. Language for legal purposes at Croatian Law Faculties is taught by studying a content-based subject, in which FL functions both as an object of teaching and a means of learning content. By this approach, Content and Language Integrated Learning (CLIL) in the field of law represents a way of learning which "is improved through increased motivation and the study of natural language seen in context" (Darn, 2006). Thereby, students are educated to be able to apply their FL knowledge in all professional situations. By means of legal terminology, they are taught the different branches of law, the differences between the Common Law System, the Continental Civil Law System and the EULaw System. They learn how to apply that knowledge in communication on legal topics and how to develop their speaking and presentation skills by giving presentations in English or German. Additionally, students are motivated to learn foreign languages by different novelties incorporated into lectures: by listening to lectures held by native speaking professors from abroad, by taking part in international seminars with fellow students from abroad, by carrying out language projects and attending language conferences, by introducing new lifelong education programmes for young lawyers, etc. 


\section{FL Teaching and Learning projects}

In the period 2005-2008, successful cooperation was established with The Robert Bosch Foundation representative Jens Wuttke, employed as a German teacher at the Law Faculty in Pecs, Hungary. A series of seminars for law students from Pecs and Osijek were organized and held in the German language. The first seminar was called IurOP 2005: Recht dreidimensional (IurOP: Law in three dimensions), in which students from both faculties gave presentations on the topics of Croatian, Hungarian and German national law systems. In the year 2006, the seminar Recht verbindet (Law connects) was organized and the following year it was named Recht europäisch (Law in the European Context). Seminars were held in the first week of May - two days in Osijek and the following two days in Pecs. The overall idea of the project was to establish contacts between the students of two neighbouring countries, to develop tolerance and respect for other cultures and nations, to widen their knowledge in the field of law and to improve their communication skills in FL.

In the period of time between 2003 and 2008, the Faculty of Law in Osijek established cooperation with the Foundation Internationale Rechtliche Zusammenarbeit. Professor Ivan Glasser, the then representative of the Foundation, held lectures twice a semester within the course "German for Lawyers", which focused on sharing experiences of German legal practice. Apart from that, Professor Glasser held public lectures for teachers and students of the Faculty of Law in Osijek concerning a case-study method for teaching law in Germany. In this way, Croatian students had the opportunity of interacting with a native speaker of German and taking part in lectures held in the same manner as in Germany.

Similar projects were developed within the course, English for Lawyers. In 2006, the Law Faculty of Osijek took part in an English Fellow Project, which enabled students of all Croatian law faculties to take part in lectures and seminars held in English by Daniela Capretti from the USA. The most recent visitor was Professor Terrence Sawyer from Gonzaga University, USA, whose visit was supported by the Fulbright Foundation, and took place in the spring of 2013. Professor Sawyer held his lectures within English Language courses using the most modern teaching methodology, audio-visual materials and movies. Thereby, Croatian law students familiarized themselves with the topics and methods used in teaching students of law in the USA. Apart from this, students of the Faculty of Law were motivated to learn foreign languages by carrying out different small projects of a linguistic character.

One of these projects was research entitled "The linguistic landscape 
of the town of Osijek", in which two teams of second year students used the fieldwork method to explore which languages are used in the town of Osijek, in its street signs and inscriptions on public buildings, as well as in the names of cafes, restaurants, shops, etc. The results were presented at the end of the winter semester this year. In cooperation with their English teacher Ljubica Kordić, representatives of the two student teams wrote a paper based on this project and presented it at the international conference of the Croatian Association of Applied Linguistics, held in Dubrovnik in April 2013. Presentation of the paper entitled the "Linguistic Landscape of the Town Osijek from a Historical Perspective" found favour with the participants of the conference, mostly experienced linguists. It was even recorded for a radio station, Croatian Radio 1, which made the students proud of their research and increased their self-confidence and motivation for learning foreign languages.

\section{Taking part in the TEMPUS-project Foreign Languages in the Field of Law}

The TEMPUS (Trans-European Mobility Programme for University Studies) supports projects between the Higher Education sector of the EU and its member states. Its main task is to foster cooperation and understanding between cultures and to facilitate university modernization by supporting structural reforms in higher education, curriculum development and innovation, teacher training and especially the mobility of academic and administrative staff from higher education institutions. The Law Faculty of Osijek participated as a Consortium member in the Tempus project Foreign Languages in the Field of Law (FLIFL) initiated by the Faculty of Law in Zagreb in 2006. It included 13 institutions from Croatia and the EU (South Bank University of London, University of Innsbruck, University of Mannheim, Université Pantheon-Assas, Paris, Forensic Linguistics Institute, Lanfair, UK). The objective of the project was to adjust the education of Croatian law students to the Bologna requirements and facilitate the integration of Croatian faculties of law into the network of European universities.

The main activities within the project were directed at two groups of experts: lawyers and teachers of foreign languages in the field of law. In that respect the project had three main goals: 1) legal education of FL teachers employed at Croatian law faculties to improve their professional credibility and excellence in LSP (teacher training programmes), 2) specialization of Croatian lawyers in foreign languages for law (lawyer training programmes) and 3) development of FL curricula and modern teaching methodology in ac- 
cordance with the Bologna requirements and the results of the needs analysis that was conducted among Croatian lawyers at the beginning of the Project. After the teacher training was finished, a series of foreign language courses in legal English and legal German were organized at Croatian law faculties. In the two last years of the project, FL courses English for Lawyers, German for Lawyers, English for EU Law and International Legal English (ILEC) were held for lawyers employed in the wider region. Altogether 138 lawyers participated in the FL training. This project was successfully carried out at the Law Faculty of Osijek and very well accepted by the local community. The fact, that the FL training of lawyers lasted for three further years after the official completion of the TEMPUS-project, confirms the sustainability of this project and its general idea that legal professionals need knowledge of foreign languages in their professional life. The knowledge and experience that FL teachers of the Law Faculty in Osijek acquired by participating in this project made them capable of developing new education programmes that would help young lawyers adjust to new political and professional circumstances and challenges.

\section{Introducing new lifelong learning programmes}

The development of innovative lifelong education programmes belongs to one of the main strategies of the University of Osijek. Lifelong learning, as defined in the document Strategy of the Josip Juraj Strossmayer University of Osijek 2011-2020, represents "one of the important guidelines for development of higher education in the European Union. Such activities require special, appropriate, and well equipped premises that can attract international students and businessmen, thus contributing to internal integration of the University, as well as to strengthening of the University internationalization. Strengthening of internal integration will be achieved through the development of lifelong learning programs by integrating expertise of various University units" (J. J. Strossmayer, 2011:54). The Department of Foreign Languages of the Faculty of Law in Osijek has initiated the introduction of a new lifelong education programme for lawyers. This was a pragmatic response to the requirements of the EU labour market being opened to Croatian lawyers. The European Personnel Selection Office (EPSO) of the European Commission announced job opportunities in the European labour market with the prospect of Croatian full membership of the EU in July 2013․ According to data from December 2012, the European Union needs translators, interpreters, lawyer linguists, administrators, heads of departments and other officials in the field of Communication, Legal Affairs and Programme Man- 


\section{Ljubica Kordić and Vesna Cigan}

agement in the offices of the European Commission, the Court of the EU and other institutions whose employees should master both legal and linguistic knowledge.

As knowledge of the EU working languages is required for future candidates, the Departments for Foreign Languages of the Law Faculty in Zagreb and the Law Faculty in Osijek initiated their Lifelong Education Programmes for Lawyer Linguists: the former in the summer semester of the year 2011/12 and the latter in the winter semester 2012/13. They organized similar programmes, adapting them to the specific circumstances of their respective faculties and the specialization of their specific teaching staff. In Osijek, the programme encompasses seven courses with a total of 130 hours. In total, 20 ECTS credits are allocated to the Programme. The programme was offered in the winter semester of 2012/2013 to graduate lawyers and $5^{\text {th }}$ year law students and was financed by a participant fee payable in instalments. The programme carried out in Osijek includes the following courses: English Legal Translation, German Legal Translation, French Legal Translation, Theory of Legal Translation and EU-Terminology, Croatian Language for Lawyer Linguists, EU Law for Lawyer Linguists and EU Vocabulary and On-line Translation Tools. It was mostly carried out by professors teaching at the Law Faculty of Osijek, but also by guest professors from the Faculty of Humanities for the courses Croatian Language for Lawyer Linguists and French Legal Translation. In the first term, 25 participants participated in this programme and the evaluation lists they filled in at the end of the programme indicate that they were very satisfied with it. By widening their knowledge in EU Law and comparative legal terminology, as well as by acquiring practical communication and translation skills in the working languages of the EU, they felt more self-confident and more qualified to meet the requirements of the opening European labour market. That is the reason why this lifelong learning programme will be offered in the next academic year as well. In accordance with the University strategy of strengthening internationalization of the University, the next step, the Department of Foreign Languages of the Law Faculty in Osijek will take, will be establishment of an interdisciplinary postgraduate course of study in Legal Linguistics. This course will offer the opportunity to acquire practical knowledge in languages and law not only to Croatian graduate students of law and philology, but also to applicants from the nearby countries Bosnia and Herzegovina and Serbia as future candidates for accession to the EU. 


\section{Conclusion}

Knowledge of foreign languages is an indispensable pre-requisite for the education of European lawyers. The awareness of the importance of FL proficiency in the legal profession is promoted by FL teachers at four Croatian law faculties in their specific approach to FL teaching: in their scientific research they have proven the importance of teaching both English and German to Croatian law students, introduced new methods and teaching approaches into their teaching process, intensified the contacts of students with native speakers of English and German and improved the excellence of their institutions by developing lifelong education programmes for law students and legal professionals. In our opinion, a step forward in the direction of adopting multilingualism as one of basic values of the modern European knowledge society, as stated by the Bologna Declaration, would be incorporating learning of the three working languages of the EU - English, French and German - into the curricula of Croatian law faculties as well as introducing e-learning as a response to the requirements of new generations of students qualified and equipped to use modern e-technologies in acquiring professional knowledge. Considering the current financial situation in Tertiary Education of the Republic of Croatia and the on-going trends concerning the status of foreign languages, we cannot be very optimistic about the realization of these ideas in near future.

\section{N O T E S}

1 http:www//europa.eu/epso/doc/epso-planing_en.pdf, accessed on Dec. 21. 2012.

\section{R E F E R E N C E S}

Cigan, V. (2013). Representation of Students Learning German at Higher Education Institutions in Zagreb. Effectus Journal. Manuscript submitted for publication.

Common European Framework of Reference for Languages - CEFR (2005) [ZEROJ (2005) Zajednički europski referentni okvir za jezike: učenje, poučavanje, vrednovanje. Vijeće Europe (2001)]. Školska knjiga. Zagreb.

Council of Europe (1982). Recommendation No. R (98) 6. Appendix to Recommendation No. $R$ in (82) 18, Measures to be implemented concerning the learning and teaching of modern languages. Council of Europe. Retrieved April 10, 2013 from https://wcd.coe.int/wcd/com.instranet.InstraServlet?command= com.instranet.CmdBlobGet\&InstranetImage $=601630 \&$ SecMode $=1 \&$ DocId $=676400 \&$ Usage $=2$. 


\section{Ljubica Kordić and Vesna Cigan}

Croatian National Education Standard [Hrvatski nacionalni obrazovni standard - HNOS. Ministarstvo znanosti, obrazovanja i športa (2005)]. Council of Europe. Retrieved from http://public.mzos.hr/Default.aspx?sec=2199.

Darn, S. (2006). Content and Language Integrated Learning. Teaching English. Retrieved April 23, 2013, from British Council \& BBC Articles database on the World Wide Web: www.teachingenglish.org.uk/articles/content-andlanguage-integrated-learning.

European Commission (1995). Weißbuch zur allgemeinen und beruflichen Bildung - Lehren und Lernen - Auf dem Weg zur kognitiven Gesellschaft. Retrieved April 10, 2013 from http://europa.eu/documentation/official-docs/whitepapers/index_de.htm.

J. J. Strossmayer University (2011a). 2010/2011 J. J. Strossmayer University of Osijek Annual Report.

J. J. Strossmayer University (2011b). 2012-2020 Strategy of the J. J. Strossmayer University of Osijek.

Kordić, Lj. (2009). Importance of Teaching German for Legal Purposes at Croatian Law Faculties. In L. Sočanac, C. Goddard \& L. Kremer (Eds.), Curriculum, Multilingualism and the Law (pp. 207-184). Zagreb: Nakladni zavod Globus.

National Curriculum Framework [Nacionalni okvirni kurikulum za predškolski odgoj i obrazovanje te opće obvezno i srednjoškolsko obrazovanje - NOK] (2010), Retrieved December 18, 2012 from http://public.mzos.hr/Default. aspx? $\mathrm{sec}=2685$.

Poljaković, I. \& Martinović, A. (2009). A New Approach to Teaching Foreign Languages in Universities. In Jagoda Granić (Ed.), Jezična politika i jezična stvarnost - Language Policy and Language Reality (pp. 225-236). Zagreb: HDPL.

Scientific Activity and Higher Education Act [Zakon o znanstvenoj djelatnosti i visokom obrazovanju] Official Gazette 123/03 (SHEA; 2003). Retrieved December 18, 2012 from http://narodne-novine.nn.hr/clanci/sluzbeni/306330. html. 